\title{
Impact of Zinc Sulfate Exposition on Viability, Proliferation and Cell Cycle Distribution of Epithelial Kidney Cells
}

\author{
Dana Marcinčáková ${ }^{1}$, Petra Schusterová ${ }^{1}$, Dagmar Mudroňová ${ }^{1}$, Tomáš Csank ${ }^{1}$, \\ Marcel Falis ${ }^{1}$, Monika Fedorová1, Slavomír Marcinčák ${ }^{1 *}$, \\ Konrad Kamil Hus², Jaroslav Legáth ${ }^{1,2}$ \\ ${ }^{1}$ University of Veterinary Medicine and Pharmacy in Košice, Košice, Slovakia \\ ${ }^{2}$ Department of Biotechnology and Bioinformatics, Faculty of Chemistry, \\ Rzeszów University of Technology, Rzeszów, Poland
}

Received: 15 June 2018

Accepted: 7 August 2018

\begin{abstract}
Zinc is an essential trace element effective at very low concentrations, but it is also an important environmental pollutant dangerous after excessive intake or exposure. The aim of this study was to evaluate in vitro nephrotoxicity of zinc sulfate heptahydrate $\mathrm{ZnSO}_{4} \times 7 \mathrm{H}_{2} \mathrm{O}(1,10,50,100,200 \mathrm{mg} / \mathrm{l})$ using rabbit epithelial kidney cells RK13 as the model cell line. The xCELLigence system (RTCA) for real-time monitoring of cell response and the end-point assays for determining metabolic activity (MTT test), cytotoxicity (LDH test), proliferation (BrdU test) and cell cycle analysis were compared. Exposure to zinc sulfate produced dose-dependent cytotoxicity. The inhibition concentration IC50 value for xCELLigence monitoring was $101.8 \mathrm{mg} / \mathrm{l}$, for MTT test $135.9 \mathrm{mg} / \mathrm{l}$ and $197.4 \mathrm{mg} / \mathrm{l}$ for BrdU test. There was a significant correlation between used assays $(p \leq 0.05)$ except for the LDH test. Based on mean of IC50 values, the effect of zinc sulfate at $150 \mathrm{mg} / 1$ on cell cycle was evaluated. We observed the accumulation of cells in S phase accompanied with the reduction of cells in the G0/G1 phase. In conclusion, the mean of our IC50 values for kidney cells is relatively high in comparison to the recommended as well as therapeutic daily doses.
\end{abstract}

Keywords: xCELLigence, MTT test, BrdU assay, LDH, cell cycle

\section{Introduction}

Zinc is an essential trace element with important biological functions that control many processes in the cell, such as DNA synthesis, normal growth, brain

*e-mail: slavomir.marcincak@uvlf.sk development, behavioural response, fetal development and bone formation [1], regulation of response to insulin, reproduction, antioxidant cellular defense systems [2] and protein synthesis [3]. Zinc is effective at very low concentrations and therefore its excessive amount in body fluids could be harmful [4].

Zinc is a serious environmental pollutant and is present in the environment. Toxicity of zinc is a 
growing concern because of nanoparticles of zinc oxide $(\mathrm{n}-\mathrm{ZnO})$ being widely used in electronics and personal care products that accumulate in aquatic and terrestrial environments from many sources. The main route of exposure is inhalation, through the skin or by ingestion. After penetration to the body it causes irritation of the respiratory or digestive system, dental deterioration and ulceration of the skin. Zinc fumes are dangerous too, and may cause fever, chills, nausea, vomiting, muscular aches and weakness [1]. Zinc administration in experimental animals at relatively high amounts can initiate tissue/cellular damage, eventually leading to death [5]. Renal cells are often exposed to higher concentrations of xenobiotics, because kidneys play the most important role in eliminating various drugs and toxic substances. According to nature, the dose, route, and duration of exposition display diverse alterations in renal function ranging from mild tubular dysfunction to severe renal failure [6]. Zinc can induce damage to kidney cells by a mechanism dependent on zinc ions entering the cell, binding to the cell organelles and disrupting cellular processes [5]. Regarding renal excretion of zinc, it is known that about 2-3 mg of zinc are replenished daily in humans [7] and less than $5 \%$ is eliminated by kidneys [8]. According to the National Institutes of Health [9], recommended dietary reference zinc intakes for adults is $8-11 \mathrm{mg}$ daily. However, higher therapeutic doses (150-660 mg daily) are indicated in some diseases, for example diabetes [10], urinary aminoaciduria [5], chronic kidney disease [11] or Wilson's disease [7]. Although many in vitro studies have indicated zinc toxicity [12-19], only a few studies have focused on its nephrotoxicity $[5,20]$. Oral treatment with zinc can change energy metabolism and cause mitochondria and cell membrane impairment in rat kidneys via inducing nephrotoxicity [21]. Therefore, we evaluated the toxicity of zinc sulfate, the common chemical form of supplemental zinc, using rabbit kidney epithelial RK13 cell line. In this work, the xCELLigence system was used for continuous real-time monitoring of cell response after zinc sulfate treatment and the commonly used assays for determining metabolic activity, proliferation and cell cycle of treated cells were employed.

\section{Experimental}

\section{Chemicals}

Tested substance Zinc sulfate heptahydrate $-\mathrm{ZnSO}_{4} \times 7 \mathrm{H}_{2} \mathrm{O}$ of analytical grade purchased from Sigma Aldrich (St. Louis, USA) was diluted in $1 \%$ dimethyl sulphoxide (DMSO; Lachema, Brno, Czech Republic) and tested at final concentrations of 1, 10, 50, 100,150 and $200 \mathrm{mg} / \mathrm{l}$. In our experiment, DMSO at $1 \%$ concentration did not affect the behaviour of cells in comparison to control cells without treatment. Zinc sulfate solutions were sterilised by filtration through a $0.22 \mu \mathrm{m}$ filter (Milipore, Watford, UK).

\section{Cell Cultivation}

Epithelial RK13 cells (rabbit kidney cell line) were obtained from the American Type Culture Collection (ATCC CCL-37). Cells were cultured in Earl's Minimal Esential Medium (EMEM; Lonza, Valais, Switzerland) supplemented with $10 \%$ (v/v) foetal bovine serum (FBS; Lonza, Valais, Switzerland) and $50 \mathrm{mg} / \mathrm{l}$ gentamicin (Sigma Aldrich; St. Louis, USA) in a humidified atmosphere of $5 \% \mathrm{CO}_{2}$ at $37^{\circ} \mathrm{C}$. In experiments, RK13 cells were cultured in complete cultivation medium without antibiotics and were regularly checked for the absence of mycoplasma contamination [22].

\section{xCELLigence System (RTCA; Real-Time Cell Analyser)}

The real-time monitoring of cell response to zinc sulfate was monitored using the xCELLigence system or real-time cell analyzer (RTCA; Roche, Applied Science, Mannheim, Germany), according to the manufacturer's instructions. This relatively new method was described in many studies [23-25]. Briefly, $100 \mu \mathrm{l}$ of antibiotic-free culture medium was added into 16-well E-plates (Roche, Applied Science, Mannheim, Germany) for the background measurement. Subsequently, $1.5 \times 10^{4}$ cells/well in $50 \mu \mathrm{l}$ of RK13-cell medium were seeded in plates and inserted into plate station, kept inside a $\mathrm{CO}_{2}$ incubator at $37^{\circ} \mathrm{C}$ with $5 \% \mathrm{CO}_{2}$ and humidified atmosphere. After $24 \mathrm{~h}$ when RK13-cells were within a log phase, the zinc sulfate in $50 \mu \mathrm{l}$ of culture medium was added to the cells. The cells treated with $1 \%$ DMSO only served as negative or solvent control. The cell response to zinc sulfate was monitored for $48 \mathrm{~h}$. Cell index (CI) was measured automatically by the RTCA system once per hour until the end of the experiment. The parameter measured to specify the effect of the tested compounds was assessed as the normalized CI. The IC50 value at a given time point ( $24 \mathrm{~h}$ after zinc sulfate treatment) was calculated based on the concentration producing $50 \%$ reduction of normalized CI value relative to solvent control.

\section{MTT (3-[4,5-dimethylthiazol-2-yl]-2,5-difenyl tetrazolium bromide) Test}

Metabolic activity was evaluated using cellular thiazol blue (3-[4,5-dimethylthiazol-2-yl]-2,5-difenyl tetrazolium bromide - MTT) uptake as an indicator of mitochondrial membrane integrity. Briefly, RK13 cells were seeded at a density of $2.2 \times 10^{4}$ cells/well in $100 \mu \mathrm{l}$ of antibiotic-free culture medium in standard 96-well culture plate (Greiner-bio-one, Kremsmünster, Austria). After $24 \mathrm{~h}$ cells were treated with zinc sulfate at tested concentrations. After $24 \mathrm{~h}$ medium was refreshed 
and cells were incubated with $0.5 \mathrm{~g} / 1$ of MTT for $4 \mathrm{~h}$ in the dark. Formazan crystals were solubilised by the addition of concentrated DMSO. Sorensen's glycine buffer $(0.1 \mathrm{~mol} / 1$ glycine, $0.1 \mathrm{~mol} / 1 \mathrm{NaCl}, \mathrm{pH} 10.5)$ was added to stabilize the final product. The absorbance was recorded at $560 \mathrm{~nm}$ (Synergy HT, Biotek, Winooski, VT, USA). Cell viability (V, \%) was expressed as fraction of the negative or solvent control.

\section{Lactatedehydrogenase (LDH) Leakage Assay}

RK13 cells were seeded in $100 \mu 1$ of antibiotic-free culture medium in a 96-well culture plate (Greiner-bioone, Kremsmünster, Austria) at a density $2.2 \times 10^{4}$ cells/ well and incubated for $24 \mathrm{~h}$ in a humidified atmosphere of $5 \% \mathrm{CO} 2$ at $37^{\circ} \mathrm{C}$. The growth medium was changed to a maintenance medium with $1 \%(\mathrm{v} / \mathrm{v}) \mathrm{FBS}$, and different concentrations of zinc sulfate were added for an additional $24 \mathrm{~h}$. After the exposure period a nonradioactive colorimetric assay was used to quantify cytotoxicity/cytolysis by measuring LDH activity released from damaged cells (Cytotoxicity Detection KitPLUS, Roche Diagnostics, GmbH, Germany). The LDH test was carried out following manufacturer's instructions. Optical density (OD) was measured in an ELISA-multiwell reader Synergy HT (Biotek, Winooski, VT, USA) at $450 \mathrm{~nm}$. To calculate percent cytotoxicity in each plate, a low-control (LC) and a high-control (HC) were set up and the percentage of cytotoxicity was calculated according to equation:

$$
\% \mathrm{C}=\left(\mathrm{ODzinc}-\mathrm{OD}_{\mathrm{LC}} / \mathrm{OD}_{\mathrm{HC}}-\mathrm{OD}_{\mathrm{LC}}\right) \times 100
$$

...in which ODzinc is the mean value of OD of treated cells, $\mathrm{OD}_{\mathrm{LC}}$ (low control) is the mean value of OD-cells treated with the solvent control (DMSO) and $\mathrm{OD}_{\mathrm{HC}}$ (high control) is the mean value of OD cells treated with the lysis buffer (the maximum releasable LDH activity in the cells) measured at $450 \mathrm{~nm}$.

\section{Bromodeoxyuridine (BrdU) Proliferation Test}

Cells were seeded the same way as in LDH assay, in $100 \mu \mathrm{l}$ of antibiotic-free culture medium in a 96-well culture plate (Greiner-bio-one, Kremsmünster, Austria) at a density of $2.2 \times 10^{4}$ cells/well and overnight incubated in a humidified atmosphere of $5 \% \quad \mathrm{CO}_{2}$ at $37^{\circ} \mathrm{C}$. Subsequently, BrdU $(10 \mu \mathrm{M})$ and different concentrations of zinc sulfate were added to the RK13 cells for $24 \mathrm{~h}$. The colorimetric immunoassay was used to quantify cell proliferation (Cell Proliferation ELISA Kit, BrdU-colorimetric, Roche Diagnostics, GmbH, Germany). This test is based on the measurement of 5-bromo-2-deoxyuridine (BrdU) incorporation during DNA synthesis. Briefly, culture medium was removed after the exposure period, DNA of the cells were denaturated and cells on the bottom of the wells were fixed. Anti-BrdU- peroxidase labelled conjugate $(100 \mu \mathrm{l})$ was added to the cells for $90 \mathrm{~min}$ at $25^{\circ} \mathrm{C}$. The immune complexes were detected by the subsequent substrate reaction (100 $\mu \mathrm{l}$ substrate solution) for 30 minutes at room temperature. The reaction was stopped by $25 \mu \mathrm{l} 1 \mathrm{M}$ $\mathrm{H}_{2} \mathrm{SO}_{4}$ and the optical density (OD) was measured in an ELISA multiwell reader Synergy HT (Biotek, Winooski, VT, USA) at $450 \mathrm{~nm}$. The mean optical densities were converted into a percentage of proliferative activity (\% PA) according to the following equation:

$$
\% \mathrm{PA}=\left(\mathrm{OD}_{\text {zinc }} / \mathrm{OD}_{\text {control }}\right) \times 100
$$

...in which $\mathrm{OD}_{\text {zinc }}$ is the mean value of $\mathrm{OD}$ of cells treated with zinc sulfate and $\mathrm{OD}_{\text {control }}$ is the mean value of OD of cells treated with the solvent only.

\section{Cell Cycle Analysis}

The effect of the zinc on RK13 cell cycle progression was assessed using flow cytometry. Cells were seeded at density $1.72 \times 10^{5}$ cells per well in standard 24-well plates. Subsequently, overnight culture was treated with zinc sulfate at a final concentration of $150 \mathrm{mg} / \mathrm{l}$. After $24 \mathrm{~h}$ incubation, both adherent and floating cells were harvested and washed in ice-cold phosphate buffered solution (PBS). Washed cells were fixed with icecold $60 \%$ ethanol and stored at $4^{\circ} \mathrm{C}$ overnight. Fixed cells were washed in PBS and resuspended in staining solution (25 mg/l propidium iodide and $100 \mathrm{mg} / \mathrm{l}$ ribonuclease $\mathrm{A}$ in PBS) and then incubated for $1 \mathrm{~h}$ at $37^{\circ} \mathrm{C}$ in the dark. Analysis was performed in a flow cytometer BD FACS Canto (BD Biosciences, San José, CA, USA) using BD FACS Diva software (BD Biosciences). The position of cells was gatted on the dot plot FSC-A vs. SSC-A and subsequently doublets and aggregates were excluded from analysis on dot plot SSC-A vs. SSC-H. DNA fluorescence signal intensity on histograms FL-2 (575/25 nm) vs. counts was used for evaluating cell cycle phases. The results are expressed as a percentage of cells having subG1 DNA content and cells in the $\mathrm{G} 0 / \mathrm{G} 1, \mathrm{~S}$ and $\mathrm{G} 2 / \mathrm{M}$ phases. A negative control consisted of cells exposed to medium with DMSO only.

\section{Statistical Analysis}

Results were expressed using the GraphPad Prism version 3.00 software (GraphPad Software, San Diego, $\mathrm{CA}, \mathrm{USA})$ as mean \pm standard deviation $(\mathrm{SD} ; \mathrm{n}=3$ ) by one-way analysis of variance (ANOVA), followed by Dunnett's multiply comparison test. The correlation coefficients $\left(\mathrm{R}^{2}\right)$ were calculated by Pearson's test.

\section{Results and Discussion}

Many in vitro studies have indicated zinc toxicity, for example to prostate cells [12], murine BAF-3 cells, 


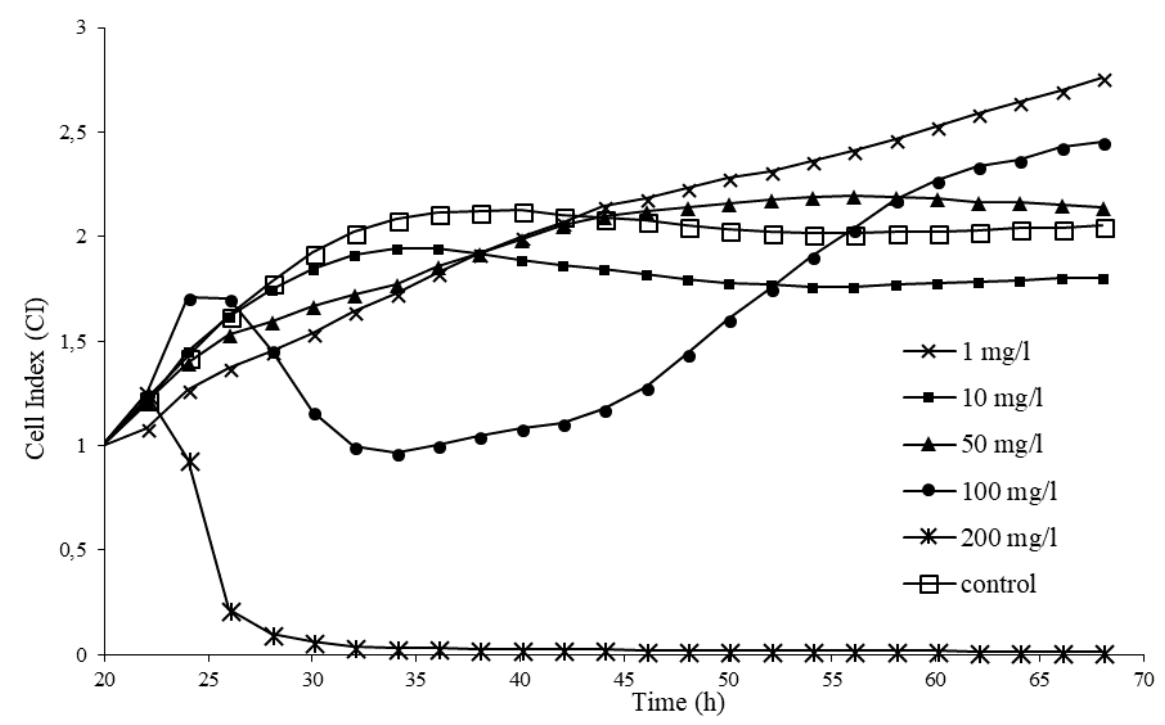

Fig. 1. The effect of zinc sulfate $(1,10,50,100,200 \mathrm{mg} / \mathrm{l})$ during $48 \mathrm{~h}$ exposition on the RK13 cell index (CI) measured by xCELLigence system (RTCA); results expressed as mean of normalized CI $(n=3)$.

human Jurkat cells [14], neuronal cells [13] as well as intestinal cells [2]. However, only a few studies have been focused on the nephrotoxicity of zinc ions $[5,20$, 21]. Therefore, we evaluated the toxicity of zinc sulfate using the kidney RK13 cell line. The concentration range has been selected according to other publications about zinc cytotoxicity $[19,26]$ as well as our preliminary studies.

At first, the xCELLigence system (RTCA) was used for real-time monitoring of cell response after zinc sulfate treatment. The RTCA system utilizes a series of microwells whose bottoms are $80 \%$ covered with microelectrodes that measure impedance changes caused by cells interacting with the microelectrodes [23]. RTCA curves respond to treatment and clearly demonstrate cell-dependent toxic responses in decreasing the measured CI. The effect of zinc sulfate during $48 \mathrm{~h}$ exposure of RK13 cells is recorded in Fig. 1. Cells treated with lower concentrations of zinc sulfate $(1,10,50 \mathrm{mg} / \mathrm{l})$ were grown similarly to control cells. Zinc sulfate at $100 \mathrm{mg} / \mathrm{l}$ concentration seems to decrease cell index in the first hours after treatment, but after a period of time the cells were able to continue growing with a slope similar to that of the control cells during their log phase at approximately $68 \mathrm{~h}$ into the experiment or about $48 \mathrm{~h}$ after treatment. A possible explanation for this observation is that the administered zinc sulfate dose did not kill all the cells in the well, or produce permanent damage to prevent them from growing. Thus, the surviving cells could continue growing after they adjusted to the conditions or the zinc sulfate concentration in the well decreased sufficiently

Table 1. The effect of zinc sulfate on adherence (RTCA), viability (MTT), cytotoxicity (LDH) and proliferation (BrdU) of the RK13 cells after $24 \mathrm{~h}$; results are expressed as mean $\pm \mathrm{SD}(\mathrm{n}=3)$.

\begin{tabular}{|c|c|c|c|c|c|c|c|}
\hline \multicolumn{2}{|c}{ Tests } & \multicolumn{7}{|c|}{ Concentration of zinc sulfate } \\
\cline { 3 - 8 } \multicolumn{2}{|c|}{} & $1 \mathrm{mg} / 1$ & $10 \mathrm{mg} / 1$ & $50 \mathrm{mg} / 1$ & $100 \mathrm{mg} / 1$ & $200 \mathrm{mg} / 1$ & Control \\
\hline \multirow{3}{*}{ RTCA } & CI & $2.15 \pm 0.16$ & $1.99 \pm 0.09$ & $2.08 \pm 0.01$ & $1.17 \pm 0.10^{* * *}$ & $0.02 \pm 0.01^{* * *}$ & $2.09 \pm 0.01$ \\
\cline { 2 - 8 } & $\%$ & $102.68 \pm 2.15$ & $95.40 \pm 4.5$ & $99.36 \pm 0.66$ & $56.15 \pm 4.93$ & $1.15 \pm 0.54$ & 100 \\
\hline \multirow{3}{*}{ MTT } & OD & $1.37 \pm 0.44^{* *}$ & $1.21 \pm 0.41$ & $1.27 \pm 0.45$ & $1.00 \pm 0.49^{* * *}$ & $0.23 \pm 0.01^{* * *}$ & $1.20 \pm 0.07$ \\
\cline { 2 - 9 } & $\% \mathrm{~V}$ & $113.47 \pm 4.5$ & $100.44 \pm 4.2$ & $105.25 \pm 4.53$ & $83.46 \pm 4.94$ & $19.22 \pm 0.84$ & 100 \\
\hline \multirow{3}{*}{ LDH } & OD & $1.09 \pm 0.00^{*}$ & $1.05 \pm 0.02$ & $2.39 \pm 0.07^{* * *}$ & $2.58 \pm 0.00^{* * *}$ & $2.24 \pm 0.01^{* * *}$ & $1.00 \pm 0.03$ \\
\cline { 2 - 9 } & $\% \mathrm{C}$ & $3.69 \pm 0.18$ & $1.91 \pm 0.76$ & $55.50 \pm 2.77$ & $62.76 \pm 0.02$ & $49.38 \pm 0.48$ & 100 \\
\hline \multirow{3}{*}{ BrdU } & OD & $0.75 \pm 0.08$ & $0.64 \pm 0.07$ & $0.56 \pm 0.06$ & $0.68 \pm 0.06$ & $0.18 \pm 0.01^{* * *}$ & $0.61 \pm 0.04$ \\
\cline { 2 - 9 } & $\%$ PA & $123.76 \pm 11.03$ & $104.84 \pm 9.37$ & $96.10 \pm 7.65$ & $107.82 \pm 10.78$ & $29.24 \pm 2.03$ & 100 \\
\hline
\end{tabular}

$\mathrm{CI}$ - cell index, OD - optical density, V - viability, C - cytotoxicity, PA - proliferative activity

Significant compared with control: ${ }^{*} p<0.05$; ${ }^{* *} p<0.01 ; * * * p<0.001$ 
Table 2. The IC50 values of zinc sulfate measured by different assays after $24 \mathrm{~h}$ exposure of RK13 cell line; results expressed as mean $(\mathrm{n}=3)$.

\begin{tabular}{|c|c|c|}
\hline \multirow{2}{*}{ RTCA } & IC50 & $101.8 \mathrm{mg} / 1$ \\
\cline { 2 - 3 } & $\mathrm{R}^{2}$ & 0.9873 \\
\hline \multirow{2}{*}{ MTT } & $\mathrm{IC50}$ & $135.9 \mathrm{mg} / 1$ \\
\cline { 2 - 3 } & $\mathrm{R}^{2}$ & 0.9759 \\
\hline \multirow{2}{*}{ LDH } & $\mathrm{IC} 50$ & $\mathrm{ND}$ \\
\cline { 2 - 3 } & $\mathrm{R}^{2}$ & - \\
\hline \multirow{2}{*}{ BrdU } & IC50 & $197.4 \mathrm{mg} / 1$ \\
\cline { 2 - 3 } & $\mathrm{R}^{2}$ & 0.8460 \\
\hline
\end{tabular}

$\mathrm{R}^{2}$ - Pearson's R square coefficient, $p-p$ value; RTCA (Real-Time Cell Analyser); MTT - (3-[4,5-dimethylthiazol2-yl]-2,5-difenyl tetrazolium bromide; LDH - lactate dehydrogenase; BrdU - 5-bromo-2-deoxyuridine

through metabolism or breakdown. With higher concentrations of zinc sulfate $(200 \mathrm{mg} / \mathrm{l}), \mathrm{CI}$ decreased in the first few hours to zero, meaning that no viable cells are attached to the microelectrodes, indicating the highest cytotoxicity.

Subsequently, based on the RTCA curves, we decided to assess zinc sulfate nephrotoxicity using end-point cytotoxic assays after $24 \mathrm{~h}$ treatment. These assays revealed that a $24 \mathrm{~h}$ exposure of RK13 cells to different concentrations of zinc sulfate produced a dosedependent reduction of cell index (RTCA), cytotoxicity (LDH test), metabolic activity (MTT test) and proliferative activity of cells (BrdU test). The response of RK13 cells is shown in Table 1. For these different assays, IC50 values were calculated too (Table 2). IC50 values at $24 \mathrm{~h}$ of incubation were calculated as the concentration of zinc sulfate inhibiting CI, metabolic activity, proliferative activity or viability of cells by $50 \%$ in comparison to a solvent-treated control. The solvent used in our study, DMSO with a final concentration of $1 \%$, did not affect the viability of RK13 cells. We found out that the IC50 values of RK13 cells for zinc sulfate was $101.8 \mathrm{mg} / \mathrm{l}$ (corresponding to $354.0 \mu \mathrm{M}$ ) for RTCA; $135.9 \mathrm{mg} / 1$ (corresponding to $472.6 \mu \mathrm{M}$ ) for MTT and $197.4 \mathrm{mg} / 1$ (corresponding to $686.2 \mu \mathrm{M}$ ) for BrdU (Table 3). These results are comparable with earlier research of SanchezMartin et al. [15], which showed that IC50 values of undifferentiated PC12 cells (from pheochromocytoma of the rat adrenal medulla) for zinc sulfate was up to $340 \mu \mathrm{M}$. The suitability of the usage of RTCA in combination with other assays for toxicity measurement was also confirmed by Xing et al. [23].

The toxic effect of zinc on kidney proximal tubular cells (LLC-PK1) has been studied recently and it has shown that zinc nephrotoxicity is in relation to zinc ions entering the cell, binding to the cell organelles and disrupting cellular processes rather than damage initiated by free radical production [5]. On the contrary, other studies showed that zinc toxicity is accompanied by a massive ROS generation [15, 27].

It has been previously reported that diverse cytotoxicity assays can give different results due to the discrepancy of the assays employed as well as different sensitivity of cell lines to the test agent $[28,29]$. We found that there is an excellent correlation between employed tests except the LDH cytotoxicity test (Table 3), for which the IC50 value was not detectable (Table 2). LDH leakage assay is based on release of the enzyme after disintegration of the cytoplasmic membrane [30]. Discrepancy between tests is most evident at the highest tested zinc sulfate concentration, where an increase in cytotoxicity is lower for LDH compared to other tests (Table 1). As mentioned above, diverse cytotoxicity/viability assays can give different results due to the discrepancy of the assays employed. The LDH test is based on release of the enzyme after disintegration of the cytoplasmic membrane and it is mainly used for determining cell necrosis [30] while other tests evaluate cells or monolayer attachment (RTCA), metabolic activity (MTT test) or proliferative activity (BrdU test) of cells - not their viability. Significantly increased LDH concentration (Table $1 ; p<0.001$ ) indicate that the mode of cell death induced by zinc sulfate was necrosis. This is supported by the results of cell cycle analysis (Fig. 2). There was no increase in the number of cells having subG1 DNA content that is considered an apoptosis marker. On the contrary, Sharma et al. [27] found that zinc oxide nanoparticles induced in human liver HepG2 cells apoptosis mediated by mitochondria pathway, but independent of JNK and p38 pathways.

In this study, the effect of zinc sulfate on the distribution of RK13 cells in each phase of the cell cycle was also determined. The selected concentration of zinc sulfate was based on the mean of our IC50 values

Table 3. Correlation between the tests used for zinc sulfate nephrotoxicity evaluation.

\begin{tabular}{|c|c|c|c|c|c|}
\hline \multicolumn{2}{|c|}{} & RTCA & MTT & LDH & BrdU \\
\hline \multirow{2}{*}{ RTCA } & $\mathrm{P}$ & - & 0.0029 & 0.3543 & 0.0495 \\
\cline { 2 - 6 } & $\mathrm{R}^{2}$ & & 0.9644 & 0.2848 & 0.7727 \\
\hline \multirow{2}{*}{ MTT } & $\mathrm{P}$ & 0.0029 & - & 0.4405 & 0.0139 \\
\cline { 2 - 6 } & $\mathrm{R}^{2}$ & 0.9644 & & 0.2077 & 0.8996 \\
\hline \multirow{2}{*}{ LDH } & $\mathrm{P}$ & 0.3543 & 0.4405 & - & 0.4784 \\
\cline { 2 - 6 } & $\mathrm{R}^{2}$ & 0.2848 & 0.2077 & & 0.1788 \\
\hline \multirow{2}{*}{ BrdU } & $\mathrm{P}$ & 0.0495 & 0.0139 & 0.4784 & - \\
\cline { 2 - 6 } & $\mathrm{R}^{2}$ & 0.7727 & 0.8996 & 0.1788 & \\
\hline
\end{tabular}

$\mathrm{R}^{2}-$ Pearson's R square coefficient, $p-p$ value; RTCA

(Real-Time Cell Analyser); MTT - (3-[4,5-dimethylthiazol-

2-yl]-2,5-difenyl tetrazolium bromide; LDH - lactate

dehydrogenase; BrdU - 5-bromo-2-deoxyuridine 
a)

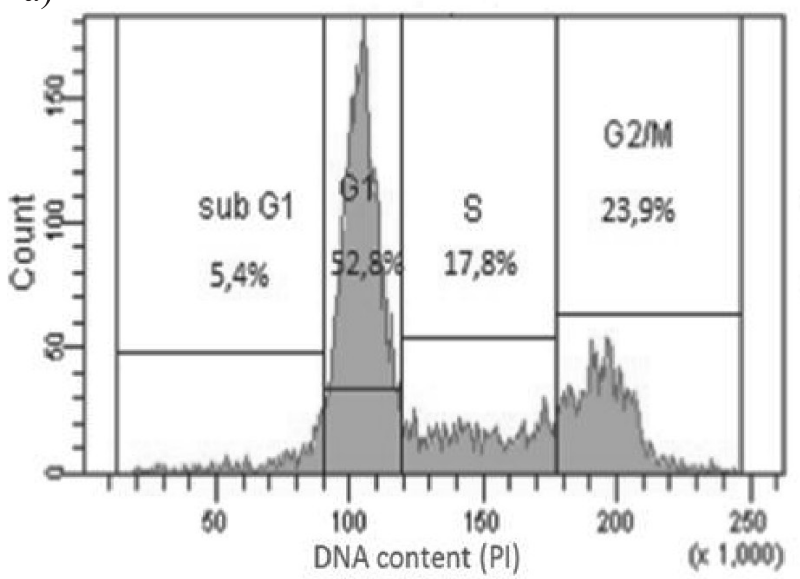

b)

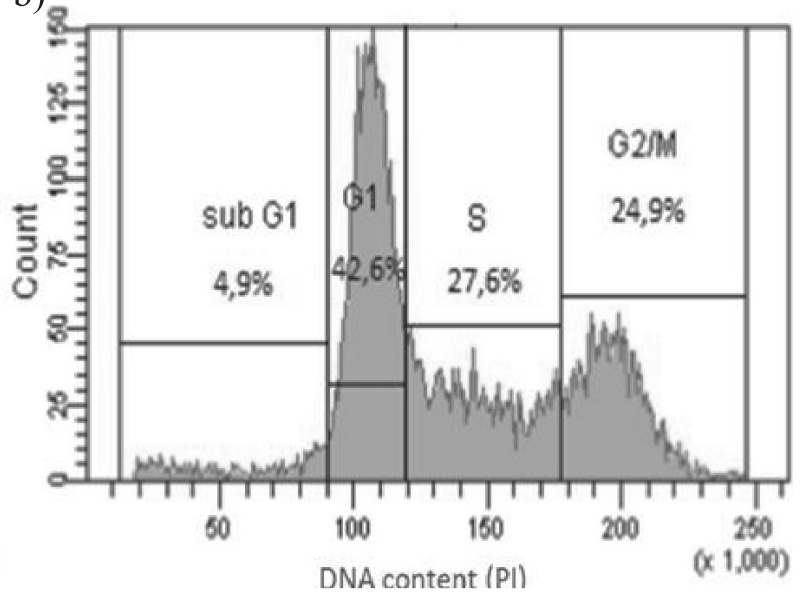

Fig. 2. Effect of zinc sulfate on the cell cycle of the RK13 cell line after $24 \mathrm{~h}$ incubation: A - negative control, B - cells were treated with zinc sulfate in $150 \mathrm{mg} / \mathrm{l}$ concentration; results are expressed as a mean $(\mathrm{n}=3)$; PI - propidium iodide.

$(150 \mathrm{mg} / \mathrm{L}, 525 \mu \mathrm{M})$. As depicted in Fig. 2, increased accumulation of cells in the $\mathrm{S}$ phase accompanied by the consequent reduction of cells in the G0/G1 phase was observed after $24 \mathrm{~h}$ treatment of RK13 cells. On the contrary, Wang et al. [19] showed that zinc sulfate $(150-200 \mu \mathrm{M})$ induced the arrest of human adenocarcinoma MDAMB231 cells in the G1 and G2/M phases. Moreover, the fraction of apoptotic MDAMB231 cells increased significantly in the presence of 200 $\mu \mathrm{M}$ zinc sulfate. Similarly, zinc induced G2/M phase arrest of human prostate cancer cells in an earlier study of Liang et al. [12]. However, Yuan et al. [16] observed no alteration in the cell cycle of human lung adenocarcinoma (A549 cells) after treatment with lower concentrations of zinc sulfate (up to $100 \mu \mathrm{M}$ ) for 6,12 and $24 \mathrm{~h}$. Mentioned studies that are not in correlation with our results used for zinc cytotoxicity assessment rapidly grew cancerous cell lines. However, some studies $[17,18]$ that used macrophages as an in vitro model are in accordance with our findings. They similarly observed zinc-induced S-G2/M cell cycle arrest accompanied with a decrease of cells in the G1 phase. The effect of zinc is clearly defined on different trophic levels after exposure to $\mathrm{n}-\mathrm{ZnO}$ of freshwater mussels Unio tumidus oxidative injury, DNA fragmentation and caspase-3 mediated apoptosis were observed [31].

\section{Conclusions}

In our work the combination of MTT, LDH, and BrdU tests with RTCA was employed. Based on the obtained results, we can conclude that the real-time monitoring of the cell response correlates significantly with commonly used biological methods for toxicity measurement except for the LDH test based on different principles. In the LDH test the higher toxicity caused an increased amount of released LDH, while in other tests the higher toxicity caused a decrease in the following parameters. The IC50 values were calculated for each of the used tests and the lowest inhibition concentration of zinc sulfate was recorded using xCELLigence system and the highest for the BrDU test. We found that the mean IC50 value of zinc sulfate $(150 \mathrm{mg} / \mathrm{l})$ caused the accumulation of RK13 cells in S phase with a simultaneous decrease of cells in the G1 phase. The toxic effect of zinc sulfate on rabbit kidney increased at a concentration-dependent manner. In conclusion, the IC50 values were relatively high in comparison to recommended as well as therapeutic daily doses.

\section{Acknowledgements}

This work was supported by the National Reference Laboratory for Pesticides of the University of Veterinary Medicine and Pharmacy in Košice and by the Ministry of Education and Science of the Slovak Republic under contract VEGA 1/0408/17.

\section{Conflict of Interest}

The authors declare no conflict of interest.

\section{References}

1. YEH Y.H., LEE Y.T., HSIEH Y.L., HWANG D.F. Dietary taurine reduces zinc-induced toxicity in male wistar rat. Journal of Food Science, 76, 90, 2011.

2. ZODL B., ZEINER M., SARGAZI M., ROBERTS N.B., MARKTL W., STEFFAN I., EKMEKCIOGLU C. Toxic and biochemical effects of zinc in CaCo-2 cells. Journal of Inorganic Biochemistry, 97, 324, 2003.

3. KLUG A. The discovery of zinc fingers and their applications in gene regulation and genome manipulation. Annual Review in Biochemistry, 79, 213, 2010.

4. BARBIER O., JACQUILLET G., TAUC M., COUGNON M., POUJEOL P. Effect of heavy metals on, and 
handling by, the kidney. Nephron Physiology, 99, 105, 2005.

5. SARGAZI M., SHENKIN A., ROBERTS N.B. Zinc induced damage to kidney proximal tubular cells: studies on chemical speciation leading to a mechanism of damage. Journal of Trace Elements in Medicine and Biology, 27, 242, 2013.

6. REYES J.L., MOLINA-JIJÓN E., RODRÍGUEZ-MUÑOZ R., BAUTISTA-GARCÍA P., DEBRAY-GARCÍA Y., NAMORADO M.D.C. Tight junction proteins and oxidative stress in heavy metals-induced nephrotoxicity. BioMed Research International, 2013

7. MARET W., SANDSTEAD H.H. Zinc requirements and the risks and benefits of zinc supplementation. Journal of Trace Elements in Medicine and Biology, 20, 3, 2006.

8. HOSNEDLOVÁ B., TRÁVNÍČEK J., ŠOCH M. Current view of the significance of zinc for ruminants: A review. Agricultura tropica et subtropica, 40, 57, 2007.

9. National Institutes of Health. Zinc. Fact sheet for Health Professionals. 2016

10. HAYEE M.A., MOHAMMAD Q.D., HAQUE A. Diabetic neuropathy and zinc therapy. Bangladesh Medical Research Council Bulletin, 31, 62, 2005.

11. NETO L.C., BACCI M.R., SVERZUTT L.C., COSTA M.G., ALVES B.C.A., FONSECA F.L. The role of zinc in chronic kidney disease patients on hemodialysis: A systemic review. Health, 8, 344, 2016.

12. LIANG J.Y., LIU Y.Y., ZOU J., FRANKLIN R.B., COSTELLO L.C., FENG P. Inhibitory effect of zinc on human prostatic carcinoma cell growth. Prostate, 40, 200, 1999.

13. PAVLICA S., GAUNITZ F., GEBHARDT R. Comparative in vitro toxicity of seven zinc-salts towards neuronal $\mathrm{PC} 12$ cells. Toxicology in vitro, 23, 653, 2009.

14. SUTHERLAND L.C., ANDERSON C.L., WILLIAMS G.T. Zinc has no effect on IL-3-mediated apoptosis of BAF-3 cells but enhances CD95-mediated apoptosis of jurkat cells. Journal of Immunological Methods, 234, 43, 2000.

15. SANCHEZ-MARTIN F.J., VALERA E., CASIMIRO I., MERINO J.M. Nerve growth factor increases sensitivity to zinc toxicity and induces cell cycle arrest in PC12 cells. Brain Research Bulletin, 81, 458, 2010.

16. YUAN N., WANG Y., LI K., ZHAO Y., HU X., MAO L., ZHAO W., LIAN H., ZHENG W. Effects of exogenous zinc on the cellular zinc distribution and cell cycle of A549 cells. Bioscience, Biotechnology and Biochemistry, 76, 2014, 2012.

17. USKI O., JALAVA P.I., HAPPO M.S., TORVELA T., LESKINEN J., MÄKI-PAAKKANEN J., TISSARI J., SIPPULA O., LAMBERG H., JOKINIEMI J., HIRVONEN M.R. Effect of fuel zinc content on toxicological responses of particulate matter from pellet combustion in vitro. Science of The Total Environment, 511, 331, 2015.

18. USKI O., TORVELA T., SIPPULA O., KARHUNEN T., KOPONEN H., PERÄNIEMI S., JALAVA P., HAPPO M., JOKINIEMI J., HIRVONEN M.R., LÄHDE A. In vitro toxicological effects of zinc containing nanoparticles with different physico-chemical properties. Toxicology in vitro, 42, 105, 2017.
19. WANG Y., ZHAO W., ZHENG W., MAO L., LIAN H., HU X., HUA Z. Effects of Different Zinc Species on Cellar Zinc Distribution,Cell Cycle, Apoptosis and Viability in MDAMB231 Cells. Biological Trace Elements Research, 170, 75, 2016.

20. WANG CH., CHENG K., ZHOU, L., HE J., ZHENG X., ZHANG L., ZHONG X.,WANG T. Evaluation of LongTerm Toxicity of Oral Zinc Oxide Nanoparticles and Zinc Sulfate in Mice. Biological Trace Element Research, 178, 276, 2017.

21. YAN G., HUANG Y., BU Q., LV L., DENG P., ZHOU J., WANG Y., YANG Y., LIU Q., CEN X. Zinc oxide nanoparticles cause nephrotoxicity and kidney metabolism alterations in rats. Journal of Environmental Science and Health, Part A, 47, 577, 2012.

22. YOUNG L, SUNG J, STACEY G, MASTERS J.R. Detection of Mycoplasma in cell cultures. Nature Protocols, 5, 929, 2010.

23. XING J.Z., ZHU L., GABOS S., XIE L. Microelectronic cell sensor assay for detection of cytotoxicity and prediction of acute toxicity. Toxicol in vitro, 20, 995, 2006.

24. ATIENZAR F.A., GERETS H., TILMANT K., TOUSSAINT G., DHALLUIN S. Evaluation of impedance-based label-free technology as a tool for pharmacology and toxicology investigations. Biosensors, 3, 132, 2013.

25. GARCIA S.N., GUTIERREZ L., MCNULTY A. Realtime cellular analysis as a novel approach for in vitro cytotoxicity testing of medical device extracts. Journal of Biomedical Materials Research Part A, 101, 2097, 2013.

26. WÄTJEN W., HAASE H., BIAGIOLI M., BEYERSMANN D. Induction of Apoptosis in Mammalian Cells by Cadmium and Zinc. Environmental Health Perspectives, 110, 865, 2002.

27. SHARMA V., ANDERSON D., DHAWN A. Zinc oxide nanoparticles induce oxidative DNA damage and ROStriggered mitochondria mediated apoptosis in human liver cells (HepG2). Apoptosis, 17, 852, 2012.

28. WEYERMANN J., LOCHMANN D., ZIMMER A. A practical note on the use of cytotoxicity assays. International Journal of Pharmaceutics, 288 (2), 369, 2005.

29. ZHU X., QIN H., LIU J., ZHANG Z., LU Y., YUAN X., WU D. A novel electrochemical method to evaluate the cytotoxicity of heavy metals. Journal of Hazardous Materials, 271, 210, 2014.

30. SIRIWAN D., NARUSE T., TAMURA H. Effect of epoxides and $\alpha$-methylene- $\gamma$-lactone skeleton of sesquiterpenes from yacon (Smallanthus sonchifolius) leaves on caspase-dependent apoptosis and NF-kB inhibition in human cercival cancer cells. Fitoterapia, 82 (7), 1093, 2011.

31. FALFUSHYNSKA H., GNATYSHYNA L., YURCHAK I., SOKOLOVA I., STOLIAR O. The effects of zinc nanooxide on cellular stress responses of the freshwater mussels Unio tumidus are modulated by elevated temperature and organic pollutants. Aquatic Toxicology, 162, 82, 2015. 